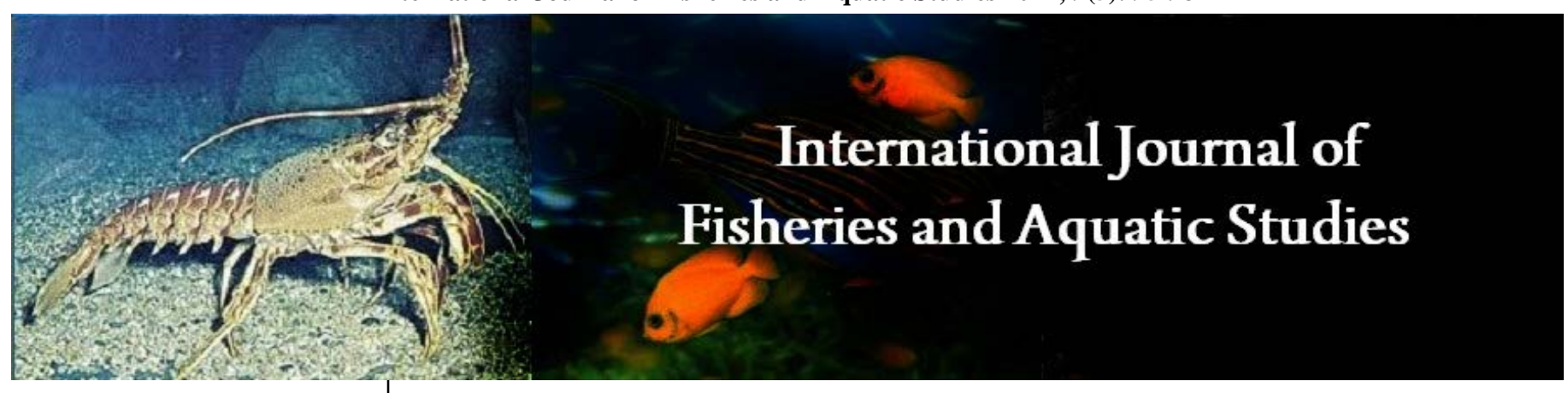

E-ISSN: 2347-5129

P-ISSN: 2394-0506

(ICV-Poland) Impact Value: 5.62

(GIF) Impact Factor: 0.549

IJFAS 2021; 9(5): 95-98

(C) 2021 IJFAS

www.fisheriesjournal.com

Received: 19-07-2021

Accepted: 26-08-2021

Shakeba Farnaz

CMJ College, Donwarihat,

Khutauna, Madhubani, LNMU,

Darbhanga, Bihar, India

Dr. Md. Rahmatullah

CMJ College, Donwarihat,

Khutauna, Madhubani, LNMU,

Darbhanga, Bihar, India

\section{Study of water quality using of Physico-chemical parameters of two perennial ponds of Darbhanga district, Bihar}

\author{
Shakeba Farnaz and Dr. Md. Rahmatullah
}

DOI: https://doi.org/10.22271/fish.2021.v9.i5b.2568

\begin{abstract}
Darbhanga district is known as city of ponds. The present investigation was undertaken the study of the physico-chemical conditions of two perennial ponds- Maharani Pokhar and Raj Pokhar of Darbhanga city. Present study revealed that physico-chemical parameters was comparatively higher of Maharani Pokhar to other pond, Raj Pokhar. The water samples were analyzed for water temperature, transparency, $\mathrm{pH}$, free $\mathrm{CO}_{2}$, chloride, carbonate, bicarbonate, magnesium, dissolved oxygen (DO) and biological oxygen demand (BOD). Higher value of physico-chemical parameters BOD, is considered to be sewage water pollution indicator for eutrophication and it also lower down the fish production.
\end{abstract}

Keywords: Physico-chemical parameters, temperature, BOD, water pollution, sewage, Darbhanga city pond.

\section{Introduction}

Darbhanga is a one of the fastest urbanizing city of north Bihar. To fulfill of water supply to its exploding population the pressure on ground water has been increasing constantly. Ground water pollution can occur where anthropogenic activity waste water is discharged into sewage drain, ponds and rivers.

Water is the most vital resource for the existence of all life and ecosystems in Earth. Certain standards in terms of its physical, chemical and biological parameters determine its suitability for intended purposes. Water is considered polluted when these parameters shift from the acceptable range of quality standards (APHA, 2000) ${ }^{[1]}$.

The pond water is generally used for domestic and fisheries activity. In India still now several researchers have done study on physic-chemical and biological characteristic of standing and running water resources (Kodarkar, 1992) ${ }^{[6]}$.

The objective of this work has to analyze various physic-chemical parameters of the pond water at Darbhanga district, Bihar.

\section{Materials and Methods}

The water samples were collected from four different stations in the morning period around 9 to $11 \mathrm{am}$., in polythene bottle regularly for once in every month and samples brought into laboratory for the estimation of various physico-chemical parameters like water temperature, transparency, $\mathrm{pH}$, were recorded at the time of collection, by using thermometer pocket digital $\mathrm{pH}$ meter, transparency was measured with the help of Secchi Disc while other parameters such as TDS, DO, BOD, free $\mathrm{CO}_{2}$, chloride, carbonate, bicarbonate and magnesium were estimated in the laboratory by using standard methods as APHA (2000) ${ }^{[1]}$, Trivedy and Goel $(1986)^{[18]}$, Kodarkar (1992) ${ }^{[6]}$.

\section{Results}

The monthly variation of certain physico-chemical parameters of both ponds Maharani Pokhar and Raj Pokhar were observed is presented in tables as follow.
Shakeba Farnaz

CMJ College, Donwarihat,

Khutauna, Madhubani, LNMU,

Darbhanga, Bihar, India 
Table 1: Physical parameters of Maharani Pokhar, Darbhanga.

\begin{tabular}{|c|c|c|c|c|}
\hline Month & $\begin{array}{c}\text { Water } \\
\text { Temperature }\end{array}{ }^{\circ} \mathbf{C}$ & $\begin{array}{c}\text { Transparency } \\
\mathbf{c m}\end{array}$ & $\begin{array}{c}\text { TDS } \\
\text { gm/liter }\end{array}$ & pH \\
\hline JAN & 20.0 & 43.2 & 0.37 & 8.5 \\
\hline FEB & 21.5 & 46.9 & 0.39 & 8.7 \\
\hline MAR & 27.5 & 45 & 0.4 & 7.6 \\
\hline APR & 28.0 & 61 & 0.2 & 7.7 \\
\hline MAY & 34.4 & 66.5 & 0.6 & 7.1 \\
\hline JUN & 32.0 & 60.5 & 2.2 & 7.1 \\
\hline JUL & 33.1 & 58 & 1.13 & 7.2 \\
\hline AUG & 33.4 & 45.5 & 0.2 & 7.5 \\
\hline SEPT & 29.5 & 46 & 0.3 & 7.6 \\
\hline OCT & 30.0 & 45 & 0.4 & 8.0 \\
\hline NOV & 29.0 & 45.2 & 1.8 & 8.1 \\
\hline DEC & 19.0 & 51 & 0.6 & 8.2 \\
\hline
\end{tabular}

Table 2: Chemical parameters of Maharani Pokhar, Darbhanga.

\begin{tabular}{|c|c|c|c|c|c|c|c|}
\hline Month & CarbonateBicarbonate & $\begin{array}{c}\text { Dissolved } \\
\text { Oxygen }\end{array}$ & $\begin{array}{c}\text { Free } \\
\mathbf{C O}_{2}\end{array}$ & BOD & Chloride Magnesium \\
\hline JAN & 3.01 & 112 & 9.0 & 0.01 & 34.50 & 28.10 & 8.30 \\
\hline FEB & 2.3 & 114 & 8.50 & 0.86 & 42.04 & 33.45 & 8.50 \\
\hline MAR & 0.0 & 109 & 9.8 & 4.00 & 49.50 & 40.10 & 14.00 \\
\hline APR & 0.001 & 257 & 6.2 & 5.28 & 72.05 & 43.40 & 16.42 \\
\hline MAY & 0.001 & 162 & 6.5 & 9.40 & 154.0 & 36.49 & 12.40 \\
\hline JUN & 0.0 & 394 & 5.3 & 10.41 & 155.8 & 34.00 & 9.20 \\
\hline JUL & 0.001 & 206 & 10.1 & 18.10 & 25.5 & 28.25 & 10.40 \\
\hline AUG & 0.0 & 195 & 7.7 & 19.10 & 27.3 & 39.00 & 6.70 \\
\hline SEPT & 0.0 & 177 & 7.0 & 16.57 & 39.4 & 46.41 & 4.10 \\
\hline OCT & 0.001 & 149 & 7.6 & 12.01 & 61.1 & 33.08 & 11.00 \\
\hline NOV & 2.4 & 150 & 8.0 & 14.50 & 21.25 & 26.25 & 11.08 \\
\hline DEC & 2.9 & 113 & 8.60 & 5.00 & 22.40 & 30.00 & 12.00 \\
\hline
\end{tabular}

Table 3: Physical parameters of Raj Pokhar, Darbhanga.

\begin{tabular}{|c|c|c|c|c|}
\hline Month & $\begin{array}{c}\text { Water } \\
\text { Temperature }\end{array}{ }^{\circ} \mathbf{C}$ & $\begin{array}{c}\text { Transparency } \\
\text { cm }\end{array}$ & $\begin{array}{c}\text { TDS } \\
\text { gm/liter }\end{array}$ & pH \\
\hline JAN & 21.0 & 51.1 & 1.37 & 8.4 \\
\hline FEB & 22.5 & 58.1 & 1.39 & 8.1 \\
\hline MAR & 26 & 73 & 0.6 & 7.6 \\
\hline APR & 28.0 & 73.5 & 0.4 & 8 \\
\hline MAY & 34.1 & 82.4 & 1.2 & 8.1 \\
\hline JUN & 31.0 & 77.1 & 1.8 & 8.3 \\
\hline JUL & 32.4 & 76 & 1.10 & 7.7 \\
\hline AUG & 31.4 & 52 & 0.2 & 8.1 \\
\hline SEPT & 28 & 53 & 0.3 & 8.0 \\
\hline OCT & 28.1 & 55 & 0.4 & 7.8 \\
\hline NOV & 27.8 & 53 & 0.8 & 8.1 \\
\hline DEC & 20.0 & 55.1 & 0.6 & 8.2 \\
\hline
\end{tabular}

Table 4: Chemical parameters of Raj Pokhar, Darbhanga.

\begin{tabular}{|c|c|c|c|c|c|c|c|}
\hline Month & CarbonateBicarbonate & $\begin{array}{c}\text { Dissolved } \\
\text { Oxygen }\end{array}$ & $\begin{array}{c}\text { Free } \\
\mathbf{C O}_{2}\end{array}$ & BOD & Chloride Magnesium \\
\hline JAN & 3.21 & 124 & 9.0 & 0.10 & 39.50 & 32.10 & 17.30 \\
\hline FEB & 4.10 & 106 & 8.50 & 0.16 & 41.04 & 36.45 & 11.50 \\
\hline MAR & 4.01 & 154 & 10.49 & 7.00 & 25.50 & 44.10 & 17.00 \\
\hline APR & 0.00 & 155 & 6.7 & 7.08 & 74.05 & 46.40 & 19.48 \\
\hline MAY & 0.00 & 225 & 7.3 & 20.40 & 124.0 & 40.49 & 15.40 \\
\hline JUN & 0.00 & 234 & 5.8 & 13.41 & 125.8 & 38.00 & 12.20 \\
\hline JUL & 0.01 & 195 & 6.18 & 12.10 & 20.5 & 34.25 & 13.40 \\
\hline AUG & 0.00 & 135 & 8.1 & 11.10 & 29.3 & 43.00 & 9.70 \\
\hline SEPT & 0.00 & 147 & 7.5 & 12.57 & 32.4 & 50.41 & 7.10 \\
\hline OCT & 0.01 & 139 & 8.1 & 7.01 & 43.1 & 37.08 & 14.00 \\
\hline NOV & 4.00 & 110 & 8.4 & 3.50 & 25.25 & 30.25 & 15.08 \\
\hline DEC & 3.0 & 115 & 9.0 & 1.00 & 25.40 & 34.00 & 10.90 \\
\hline
\end{tabular}

\section{Discussion}

The physico-chemical analysis of the two ponds water has been made during different season of a year of observation. The detail of observation may be discussed in relation to the previous works done by the different workers.
Temperature: Water temperature of Maharani pond was recorded maximum in month of May (summer) $34.4^{\circ} \mathrm{C}$ and in December (winter) $19{ }^{\circ} \mathrm{C}$ while in Raj pond maximum in month of May (summer) $34.1^{\circ} \mathrm{C}$ and in December (winter) 20 ${ }^{\circ} \mathrm{C}$. Temperature is amongst one of the important factors that has direct effect over the survival and existence of living organisms as well as physico-chemical quality of water. Temperature of the pond water showed typical seasonal fluctuation as it was recorded maximum in summer and minimum in winter. Yearly mean of the temperature was observed higher in pond water during the summer but lower in winter. Vyas and Kumar (1968) ${ }^{[21]}$ have found similar results.

Transparency: Water transparency of Maharani pond was recorded maximum in month of May (summer) $66.5 \mathrm{~cm}$ and in October (winter) $45 \mathrm{~cm}$ while in Raj pond maximum in month of May (summer) $82.4 \mathrm{~cm}$ and in January (winter) 51.1 $\mathrm{cm}$. higher transparency occur during winter and summer due to absence of rain, runoff and flood water as well as gradual setting of suspended particles. Higher transparency in winter was also reported by Bhatt et al. (1985) [2]. However, Towhead et al. (1988) observed maximum transparency during the winter. Minimum transparency was observed during the rains, has also been observed by several investigators including Bhatt et al. (1985) ${ }^{[2]}$ and Towhead et al. (1988).

pH: Water pH of Maharani pond was recorded minimum in month of May (summer) 7.1 and in October (winter) 8.7 while in Raj pond minimum in month of June (summer) $7.7 \mathrm{~cm}$ and in January (winter) 8.4. Most commonly it varies between 7 and 9. In commonest water, $\mathrm{pH}$ is slightly alkaline due to the presence of bicarbonates and carbonates of alkaline earth. Seulpthorpe (1976) ${ }^{[13]}$ has suggested that $\mathrm{pH}$ and carbon dioxide are even more critical factors in the survival of aquatic plant and fishes then the oxygen supply. Alternations in $\mathrm{pH}$ in natural waters are usually accompanied by changes in other physico-chemical factors also. It is therefore very essential to monitor the level of $\mathrm{pH}$ in a given water body regularly in view of its implication. Its level fluctuated in within a narrow range in conformity with the findings of various workers (Hosmani and Bharati, 1980; Mesfin and Belay, $1989^{[7]}$ and Surabhi, 1994) ${ }^{[5,16]}$.

TDS of Maharani pond water was recorded maximum in month of June (rainy season) $2.2 \mathrm{gm} / \mathrm{L}$ and in April (before summer) $0.2 \mathrm{gm} / \mathrm{L}$ while in Raj pond maximum in month of July (rainy season) $82.4 \mathrm{~cm}$ and in April (before summer) 0.4 $\mathrm{gm} / \mathrm{L}$. It is due to heavy rainfall. Similar records were observed to reported by Verma and Munshi (1987) ${ }^{[19]}$ and Towheed et al. (1988) ${ }^{[17]}$.

DO: The amount of oxygen in water depends on the surface area exposed, temperature and salinity. Water, where organic matter is very high, has very little oxygen dissolved in it and self-purification of water system depends on the presence of sufficient amount of oxygen dissolved in it. Dissolved Oxygen was found to be maximum during the winters in both ponds. This can be attributed to the prevailing lower temperature. Solubility of oxygen is dependent on temperature and it increases with decrease in water temperature (Clarke, 1965) ${ }^{[3]}$. Higher amount of dissolved oxygen during the winters have also been reported by Vyas 
and Kumar (1968) ${ }^{[21]}$, Bhatt et al. (1985) ${ }^{[2]}$ and Towheed et al. (1988) ${ }^{[17]}$. Minimum content of Dissolved Oxygen was observed during the rains and summers, a result also observed by Verma and Munshi (1987) ${ }^{[19]}$ and Towheed et al. (1988) [17].

BOD: Biological Oxygen Demand is an important parameter for assessing water quality. When oxygen is used up faster than it is replaced, the water quality begins to deteriorate. Water BOD of Maharani pond was recorded maximum in month of May (summer) 155.5 ppm and minimum in November (winter) $20 \mathrm{ppm}$ and rainy season while in Raj pond maximum in month of May (summer) 125.8 ppm and in July (rainy season) $20 \mathrm{ppm}$ occur during rainy season due to runoff water. The similar result also observed by Verma and Munshi (1987) ${ }^{[19]}$ and Towheed et al. (1988) ${ }^{[17]}$.

Carbonate \& Bicarbonate: Seasonal mean was maximum in winter and minimum in summer in both ponds water. Carbonate alkalinity was low whereas bicarbonate alkalinity was recorded fairly high. The lower levels carbonate alkalinity and higher level of bicarbonate alkalinity can be attributed to the $\mathrm{pH}$ range which favours more $\mathrm{CO} 2$ to be present as HCO3 ion (Clarke, 1965) ${ }^{[3]}$. High value of bicarbonate alkalinity in polluted water have been reported by Singh (1985) ${ }^{[14]}$ and Sahay et al. (1985). Based on alkalinity values, Moyle (1946) ${ }^{[9]}$ classified water into three categories : low productive with less than 20 ppm alkalinity, low to medium with 20-40 ppm alkalinity and medium to high with 40-90ppm alkalinity. Philipose (1959) ${ }^{[10]}$ categories Indian water as low productive having 40-50 alkalinity, moderately high with 50-100 ppm alkalinity and fairly high with 100-200 ppm alkalinity. On the basis of these classifications, the pond under study appear to be of good productive value. The property of water which prevents leather formation with soap is called hardness and is mainly caused by the calcium and magnesium cations. However, other cations and anions also contribute to hardness. Hard water is not suitable for various domestic purposes. It has no adverse effect on health but highest desirable limit of $100 \mathrm{mg} / \mathrm{l}$ and maximum permissible limit of $500 \mathrm{mg} / \mathrm{l}$ have been set by WHO for drinking water. However, Ministry of Works and Housing (1975) considers $200 \mathrm{mg} / \mathrm{l}$ as acceptable and a concentration of $600 \mathrm{mg} / \mathrm{l}$ as cause of rejection.

$\mathbf{C O}_{2}$ : Water with concentration of free $\mathrm{CO}_{2}$ less than $5 \mathrm{ppm}$ supports good fish production, where as its high concentration in water leads to asphyxiation and obtain death of fishes. As far as prediction of the trophic status of a water body on the basis of recording of annual mean values of free $\mathrm{CO} 2$ is concerned, there are difference in opinions. Yadava et al. (1987) ${ }^{[22]}$ and Hosmani (1988) ${ }^{[4]}$ have observed decrease value of free $\mathrm{CO} 2$ in eutrophic and polluted water bodies and on the other hand Hosmani and Bharti (1980) ${ }^{[5]}$, Mesfin and Belay (1989) ${ }^{[7]}$, Rana and Palria (1998) ${ }^{[12]}$, have ascertained lower free $\mathrm{CO} 2$ content at unpolluted sites. Thus, CO2 concentration appears to be no yard stick for predicting either the trophic level or magnitude of pollution of any water body.

Chloride: Water BOD of Maharani pond was recorded maximum in month of May (summer) $46.5 \mathrm{ppm}$ and minimum in November (winter) 26 ppm while in Raj pond maximum in month of May (summer) $50 \mathrm{ppm}$ and in January (winter) 32 ppm occur. None of the values exceeded desirable standard (200ppm) of WHO and Ministry of Works and Housing in the water of pond and river. High chloride content in the polluted water has been reported by Venue et al. (1984) ${ }^{[20]}$, Singh (1985) ${ }^{[14]}$, High chloride content in the polluted water has been reported Venue et al. (1984) ${ }^{[20]}$, Singh (1985) ${ }^{[14]}$ and Rana and Palria (1988) ${ }^{[12]}$.

Magnesium: is an important major nutrient needed by all organisms, since it activates many enzyme systems. It is an essential constituent of the chlorophyll and is also involved in phosphorus transfer process. It is particularly associated with clay. It plays an important role in synthesis of ATP and ADP and inorganic phosphates. It is also an activator for many of the enzymes involved in carbohydrate metabolism. In the present study, yearly mean of magnesium was found to be lower in the rainy season and higher in winter. The highest desirable limit of magnesium in drinking water prescribed by WHO and acceptable limit to Ministry of Works and Housing is 30ppm. Thus existing level of magnesium in pond and river water is within the maximum desirable limit of WHO and acceptable limit of Ministry of Works and Housing Prasad and Singh (1982) ${ }^{[11]}$ recorded higher values of magnesium of polluted station (35.36 ppm) in comparison with unpolluted station (17.13 ppm) of Gomati river at Lucknow. Singh et al. (1970) during their study of the algal flora of sewage recorded the range of magnesium between 15.4 and 85.0ppm. Singh (1992) [15] recorded minimum magnesium level during monsoon months and the maximum in the month of February. Therefore, it may be concluded that the both ponds water under study is not polluted as far as magnesium is concerned.

\section{Conclusion}

Observed values of Maharani pond water on Temperature, magnesium, carbonate, chloride, $\mathrm{BOD}$ and free $\mathrm{CO}_{2}$ were found comparatively higher than that of Raj pond, whereas $\mathrm{pH}$, Transparency, Dissolved Oxygen and bicarbonate of Maharani pond water were found lower than the Raj pond.

\section{Acknowledgement}

The authors are thankful to the Department of Zoology, Marwari College, Darbhanga, LN Mithila University, Darbhanga, for the provision of laboratory facilities used in this study.

\section{References}

1. APHA. Standard Methods for the Examination of Water and Wastewater. 20th ed., Analysis of Water and Wastewater, American Public Health Association, Washington DC, USA 2000.

2. Bhatt SD, Bisht Y, Nagi U. Hydrology and phytoplankton population in river Kosi of the Western Himalaya (Uttar Pradesh). Indian. J. Ecol. 1985;12(1):141-146.

3. Clarke GL. Elements of Ecology. Publ. John Wiley \& Sons, inc., New York. London. Sydney 1965, 560.

4. Hosmani SP. Seasonal changes in phytoplankton communities in a fresh water pond at Dharwar, Karnatak state, India, Phykos 1988;27(1-2):82-87.

5. Hosmani SP, Bharati SG. Limnological studies in ponds and lakes of Dharwad. Comparative phytoplankton ecology of water bodies. Phykos 1980;19(1):27-43.

6. Kodarkar MS. Methodology for water analysis, physicchemical, Biological and Microbiological Indian Association of Aquatic Biologists Hydrabad; Pub 
1992;2:50.

7. Mesfin M, Belay A. A study of seasonal fluctuation of phytoplankton in relation to water quality in Lege Dadi Reservoir. International J. of Ecol \& Environ Sci 1989;15(1):1-16.

8. Ministry of Works and Housing Drinking Water Standards 1975. In "Chemical and biological methods for water pollution studies" by Trivedi, R.K. and Goel, P.K, Environmental Publications, Karad, Maharastra, India 1984.

9. Moyle JB. Some indices of lake productivity. Trans. Amer. Fish Soc 1946;76:322-334.

10. Philipose. Fresh water phytoplankton of inland fisheries. Proc. Symp. Algology 1959;4:241-262.

11. Prasad BN, Singh Y. On diatom as indicator of water pollution. J. Indian Bot. Soc 1982;61:326-336.

12. Rana BC, Palria S. Phycological \& Physico-chemical Evalution of the river Ayad, Udaypur. Phykos 1988;27(12),211-217.

13. Seulthope CD. Biology of aquatic vascular plants. Edward Amold (Pub) Ltd. London 1976, 10.

14. Singh AK. Physico-chemical and bacterial study of sewage water discharged into the river Ganga at Bhagalpur, India. Environment and Ecology 1985;3(2):138-142.

15. Singh MP. Limnological studies of Sikandarapur Ox-bow lake with reference to algal diversity. Ph.D. Thesis, B.R.A. Bihar university, Muzaffarpur 1992.

16. Surabhi. Limnological studies of Dighi pond at Darbhanga (Bihar), Phycological Laboratory, University Department of Botany, B.R.A.Bihar University, Muzaffarpur 1994.

17. Towheed MA, Singh RK, Singh BN. Physico-chemical factors of swamps of Kosi region and manin Kosi river of north eastern Bihar in relation to yield by air-breathing fishes. Environment and Ecology 1988;6(2):386-389.

18. Trivedy RK, Goel PK. Chemical and Biological methods for water pollution studies, Environmental Publication, Karad Maharashtra 1986.

19. Verma Prem Kumar, Munshi Jayashree D. Plankton community structure of Badua reservior, Bhagalpur (Bihar), Trop. Ecol 1987;28:200-207.

20. Venu P, Kumar V, Sardana RK, Bhasin MK. Indicatory and functional role of phytoplankton in effluents of rangpo distilleries of Sikkim Himalayas. Phykos 1984;23(1-2):38-44.

21. Vyas LN, Kumar HD. Studies on the Phytoplankton and other algal of Indrasagar tank, Udaipur, India. Hydrobiologia 1968;31:421-434.

22. Yadava YS, Singh RK, Choudhary M, Kolekar V. Limnology and productivity of Dighali Beel (Assam), Trop. Ecol 1987;28:137-146. 